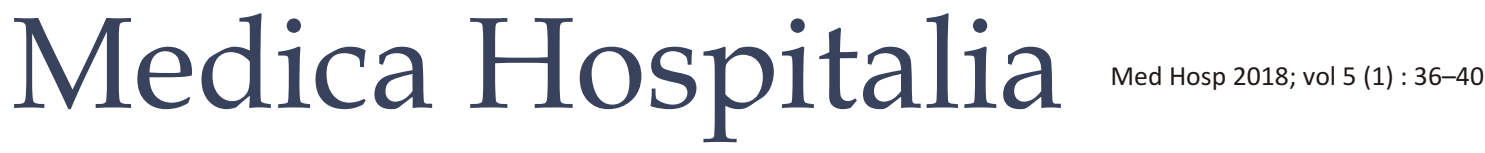

Original Article

\section{Hubungan Ratio Trigliserida/HDL-C dengan HbA1c pada Penderita Diabetes Melitus Tipe 2}

\author{
Obed Huger Nainggolan ${ }^{1}$, Herniah Asti Wulanjani² \\ ${ }^{1}$ Program Studi Patologi Klinik Fakultas Kedokteran Universitas Diponegoro / RSUP Dr. Kariadi Semarang \\ ${ }^{2}$ Bagian / KSM Patologi Klinik Fakultas Kedokteran Universitas Diponegoro / RSUP Dr. Kariadi Semarang
}

\begin{abstract}
Abstrak
Latar belakang : Diabetes Melitus tipe 2 meliputi 90\% dari semua populasi diabetes. Peningkatan prevalensi diabetes melitus dapat disertai dengan peningkatan prevalensi penyakit kardiovaskuler. Salah satu faktor risiko terjadinya PJK pada DM tipe 2 adalah dyslipidemia. Dislipidemia adalah gangguan metabolisme lipid, dimana yang paling sering ditemukan adalah peningkatan kadar Trigliserida dan penurunan kadar HDL-C. Penelitian menunjukan bahwa menurunkan HbA1c dapat menunda atau mencegah komplikasi kronik. Penelitian ini bertujuan untuk mengetahui hubungan ratio Trigliserida/HDL-C dengan $\mathrm{HbA1c}$ pada penderita DM tipe 2

Metode : Penelitian potong lintang pada rekam medik 59 pasien Diabetes Melitus tipe 2 di RSUP Dr. Kariadi. Kadar Profil Lipid terdiri dari Kolesterol Total, Trigliserida, HDL-C, LDL-C diperiksa dengan metoda kolometrik enzimatik, kadar HbA1c dengan metoda turbidimetri.

Hasil : Korelasi ratio Trigliserida /HDL-C dengan kadar HbA1c adalah 0,152 ( $p=0,250$ yang menandakan bahwa ada hubungan yang positif namun tidak signifikan antara ratio Trigliserida/HDL-C dengan kadar HbA1c.

Simpulan : Tidak terdapat hubungan antara ratio Trigliserida /HDLC dengan kadar HbA1c.
\end{abstract}

Kata kunci : Trigliserida, HDL-C, HbA1c, DM tipe 2

\section{Correlation between the ratio triglyceride/HDL-C and hba1c in type 2 diabetes mellitus patients}

\begin{abstract}
Background : Type 2 Diabetes Mellitus accounts for $90 \%$ of all diabetic population. Increased prevalence of diabetes mellitus may be associated with an increased prevalence of cardiovascular disease. One of risk factors for Coronary Heart Disease in type 2 diabetes mellitus is dyslipidemia. Dyslipidemia is lipid metabolism disorders with an increased levels of Triglyceride and decreased HDL-C levels are the most common symptoms. Studies showed that lowering $\mathrm{HbA} 1 \mathrm{c}$ numbers could delay or prevent chronic complications. The objectives of this study was tto determine the correlation between the ratio Triglyceride/HDL-C and HbA1c in patients with type 2 diabetes mellitus.

Methods : This was a cross-sectional study where data were collected from medical record of 59 type 2 diabetes mellitus patients at RSUP Dr. Kariadi. Lipid profile consisted of Total cholesterol, Triglyceride, HDL-C, LDL-C levels which were measured using enzimatik colometric method. HbA1c level which was measured by turbidimetric method.

Results : The correlation of Triglyceride / $\mathrm{HDL}-\mathrm{C}$ ratio and $\mathrm{HbA1c}$ were $0.152(p=0.250)$, which indicates that there is a positive but not significant relationship between the ratio TG/HDL-C with HbA1clevels.

Conclusion : There was a no correlation between the ratio TG/ HDL-C with HbA1c levels.
\end{abstract}

Keywords : Triglycerides, HDL-C, HbA1c, and diabetes mellitus type 2. 


\section{PENDAHULUAN}

Hiperglikemia merupakan salah satu tanda khas penyakit diabetes melitus (DM), meskipun juga mungkin didapatkan pada beberapa keadaan yang lain. Saat ini penelitian epidemiologi menunjukkan adanya kecenderungan peningkatan angka insidensi dan prevalensi penyakit DM tipe 2 di berbagai penjuru dunia. ${ }^{1}$

Diabetes Melitus tipe 2 meliputi 90\% dari semua populasi diabetes. Prevalensi DM tipe 2 pada bangsa kulit putih berkisar antara 3-6\% dari orang dewasanya. Angka ini merupakan baku emas untuk membandingkan prevalensi diabetes antar berbagai kelompok etnik di seluruh dunia. ${ }^{2}$

Diabetes Atlas 2000 (International Diabetes Federation) mencantumkan perkiraan penduduk Indonesia di atas 20 tahun sebesar 125 juta jiwa dan asumsi prevalensi DM sebesar 4,6\%, jika pada tahun 2000 penderita DM berjumlah 5,6 juta pasien, maka diperkirakan pada tahun 2020 nanti jumlah penderita DM menjadi 8,2 juta pasien dengan jumlah penduduk di atas 20 tahun sejumlah 178 juta jiwa. ${ }^{3}$

Tindakan pengendalian DM sangat diperlukan, khususnya dengan mengusahakan tingkat gula darah sedekat mungkin dengan normal, merupakan salah satu usaha pencegahan yang terbaik terhadap kemungkinan berkembangnya komplikasi dalam jangka panjang. ${ }^{5}$ Peningkatan prevalensi diabetes melitus dapat disertai dengan peningkatan prevalensi penyakit kardiovaskuler. Hal ini didasarkan dari penyebab utama morbiditas dan mortalitias pada pasien diabetes adalah penyakit kardiovaskuler, serta saat ini diketahui bahwa diabetes melitus memiliki risiko yang equivalent dengan penyakitjantung koroner(PJK) sekitar $80 \%{ }^{4-7}$

Salah satu faktor risiko terjadinya PJK pada DM tipe 2 yaitu dislipidemia, yaitu gangguan metabolisme lipid berupa peningkatan kadar kolesterol total, trigliserida (TG), low density lipoprotein-cholesterol (LDL-C), dan penurunan kadar high density lipoprotein-cholesterol (HDL-C). $4,5,8-10$

Gambaran dislipidemi pada DM tipe 2 yang paling sering ditemukan adalah peningkatan kadar TG dan penurunan kadar HDL. Walaupun kadar LDL tidak selalu meningkat, tetapi partikel LDL akan mengalami penyesuaian perubahan (modifikasi) menjadi bentuk kecil dan padat yang bersifat aterogenik. ${ }^{4,5,10}$

Penelitian epidemiologi maupun uji klinik menunjukkan adanya hubungan linier antara dislipidemi diabetik dengan angka kejadian dan angka kematian akibat PJK di penderita DM tipe $2 .^{6}$ Adam melaporkan adanya kadar TG meningkat secara bermakna pada $43,2 \%$ penderita DM tipe 2 di Makassar tahun 2001-2004. ${ }^{7}$ Hal ini menunjukkan bahwa relatif masih sedikit studi prospektif lipid sebagai prediktor PJK di penderita DM tipe $2.4,8$
Penelitian lain menunjukkan bahwa faktor risiko yang memiliki asosiasi pada kejadian PJK pada diabetes melitus adalah komplikasi microvascular dan terapi farmakologi yang digunakan oleh penderita diabetes. ${ }^{11}$ Salah satu faktor risiko komplikasi microvascular pada diabetes adalah kendali glikemik yang buruk. ${ }^{12}$ Oleh karena itu, kendali glikemik yang buruk diperkirakan memiliki kontribusi terhadap perubahan profillipid pada pasien DM tipe 2. Profillipid yang buruk merupakan salah satu faktor risiko PJK pada pasien diabetes melitus tipe2. ${ }^{13-17}$

Berdasarkan penelitian sebelumnya ditemukan bahwa kondisi hiperglikemik memiliki efek langsung dan tidak langsung terhadap kondisi pembuluh darah. ${ }^{12}$ Efek tidak langsung kondisi hiperglikemik diperkirakan melalui pengaruhnya terhadap profil lipid. ${ }^{12}$

Temuan utama studi diabetes oleh Diabetes Controland Complication Trial (DCCT) telah menunjukan pentingnya tes $\mathrm{HbA1c}$. Studi menunjukan bahwa menurunkan angka $\mathrm{HbA1c}$ dapat menunda atau mencegah komplikasi kronik. ${ }^{18}$

Tujuan dari penelitian ini adalah untuk membuktikan apakah ada hubungan ratio TG/HDL-C dengan $\mathrm{HbA1}$ c pada penderita DM tipe 2 .

\section{METODE}

Desain penelitian ini adalah belah lintang yang dilaksanakan dari periode November 2015 sampai Maret 2016 di RSUP Dr Kariadi Semarang. Data penelitian ini menggunakan data sekunder (rekam medis) pasien yang memenuhi kriteria inklusi di antaranya: penderita DM tipe 2, memiliki catatan pemeriksaan $\mathrm{HbA1c}$ dan profil lipid lengkap. Sedangkan kriteria eksklusi antara lain: penderita DM tipe 1 , penderita DM tipe 2 dengan anemia, dan penderita DM tipe 2 yang menggunakan obat penurun lipid. Besar sampel dalam penelitian ini adalah 59 sampel yang dipilih dengan metoda purposive sampling.

Variabel bebas adalahProfil Lipid yaitu kadar kolesterol total, trigliserid, HDL dan LDL yang diukur dengan metoda kolometric enzimatik sedangkan variable terikat adalah kadar HbA1c yang diukur dengan metoda turbidimetri.

Data diolah menggunakan program komputer, masing-masing variabel numerik dilakukan uji normalitas. Pada uji Test of Normality Kolmogorov Smirnov, skor Trigliserida/HDL mempunyai nilai $p=0,000$ dan skor HbA1c mempunyai nilai $p=0,200$. Salah satu nilai $p<0,05$, maka dapat disimpulkan kedua kelompok data mempunyai distribusi yang tidak normal. Data penelitian ini kemudian diuji dengan korelasi Spearman dengan tingkat kemaknaan $(\mathrm{p}) p<0,05$. 


\section{HASIL}

Subjek penelitian terdiri dari 59 pasien yang berusia minimal 18 tahun dan maksimal 78 tahun, dengan median 55 tahun. Distribusi data ditampilkan pada tabel 1.

Sebagian besar subjek masih memiliki kontrol gula darah yang buruk dengan profil lipid yang kurang baik pula. Kadar asam urat relatif normal Karakteristik subjek ditampilkan pada tabel 2.

Nilai korelasi yang didapatkan untuk pengujian hubungan antara ratio TG/HDL dengan kadar HbA1c adalah 0,152 (korelasi positif). Perolehan nilai $p$ dihitung $=0,250>0,05$ yang menandakan bahwa ada hubungan yang positif antara ratio TG/HDL dengan kadar $\mathrm{HbA1c}$ tetapi tidak signifikan.

\section{DISKUSI}

Berdasarkan hasil dari penelitian yang telah dilaksanakan selama kira-kira lima bulan dimana 59 orang menjadi sampel penelitian, dapat diperoleh gambaran bahwa untuk kategori jenis kelamin, diperoleh jenis kelamin laki-laki lebih banyak dibanding perempuan. Penelitian yang dilakukan oleh Rheza Priyadi juga menunjukkan hasil yang sama, dimana penderita DM tipe 2 terbanyak berjenis kelamin lakilaki. $^{22}$

\section{TABEL 1}

\section{Deskriptif Umum Jenis Kelamin}

\begin{tabular}{lll} 
Karakteristik & n & (\%) \\
\hline Laki-laki & 31 & 52,5 \\
Perempuan & 28 & 47,5 \\
\hline
\end{tabular}

\section{TABEL 2}

\section{Karakteristik Data}

\begin{tabular}{lcc} 
Kategori & Mean \pm SD & Min - Maks \\
\hline Umur (tahun) & $56,15 \pm 11,06$ & $18-78$ \\
Hb (g/dL) & $13,9 \pm 1,19$ & $12-17,1$ \\
HbA1c (\%) & $10,55 \pm 2,53$ & $5,6-18,6$ \\
Trigliserida (mg/dL) & $224,86 \pm 252,01$ & $45-1919$ \\
HDL (mg/dL) & $37,85 \pm 18,33$ & $6-139$ \\
Ratio Trigliserida/HDL & $8,82 \pm 13,06$ & $1,34-58,5$ \\
LDL (mg/dL) & $125,51 \pm 47,52$ & $17-221$ \\
Kolesterol Total (mg/dL) & $202,08 \pm 59,49$ & $104-449$ \\
Asam urat (mg/dL) & $5,62 \pm 2,32$ & $1,9-10$ \\
GDP (mg/dL) & $221,76 \pm 84,97$ & $59-434$ \\
G2PP (mg/dL) & $296,58 \pm 91,28$ & $96-491$
\end{tabular}

TABEL 3

Hasil Uji Korelasi Spearman's rho untukhubungan antara ratio TG/HDL-C dengan HbA1c pada penderita DM tipe

\begin{tabular}{lccc} 
Variabel & Min - Maks & $\boldsymbol{p}$ & Min - maks \\
\hline Rasio Trigliserida/HDL & $\begin{array}{r}1,34-58,5 \\
5,6-18,6\end{array}$ & 0,250 & 0,152 \\
HbA1c (\%) & &
\end{tabular}




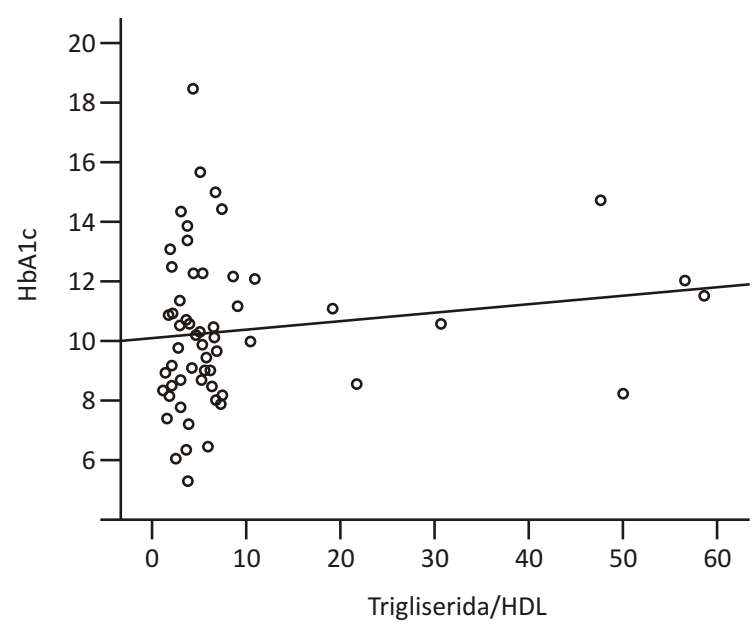

Gambar 1. Korelasi antara ratio TG/HDL dengan kadar HbA1c

Uji hubungan antara ratio TG/HDL dengan kadar HbA1c,nilai korelasinya adalah 0,152 (korelasi positif). Perolehan nilai $p$ dihitung $=0,250>0,05$ yang menandakan bahwa ada hubungan yang positif antara ratio TG/HDL dengan kadar $\mathrm{HbA1c}$ tetapi tidak signifikan.

Hal ini sama dengan penelitian sebelumnyayang dilakukan oleh Gloria Stevani dan kawan-kawan serta oleh UNAND. Penelitian ini menunjukan bahwa tidak adanya hubungan signifikan antara kadar $\mathrm{HbA1c}$ dengan kadar Trigliserida dan HDL. ${ }^{19,20}$

Korelasi positif artinya semakin tinggi nilai $\mathrm{HbA1c}$, semakin tinggi ratio TG/HDL dalam darah. Hal ini bisa dijelaskan melalui patogenesis DM tipe 2 saat fase lanjut. Dimana pada fase ini, kelebihan glukosa dalam darah disimpan dalam bentuk lemak, khususnya trigliserida. Sehingga jika kendali glikemik buruk (ditunjukkan dengan nilai HbA1c yang tinggi), akan menimbulkan peningkatan kadar glukosa dalam darah. Selanjutnya glukosa diubah menjadi trigliserida, sehingga terjadi peningkatan kadar trigliserida. Peningkatan kadar trigliserida akan diikuti dengan penurunan kadar HDL di dalam darah.

Teori menunjukan bahwa semua bagian lipid seperti Kolesterol Total, LDL, dan Trigliserida akan meningkat secara signifikan pada penderita diabetes. ${ }^{23}$ Temuan dari sebuah studi dengan jelas menunjukan bahwa HbA1c tidak hanya berguna sebagai biomarker jangka panjang kontrol glikemik, tetapi juga prediktor yang baik dari profil lipid. Pengawasan kontrol glikemik menggunakan $\mathrm{HbA1c}$ bisa memiliki manfaat tambahan mengidentifikasi pasien diabetes yang berada pada resiko yang lebih besar dari komplikasi kardiovaskular. ${ }^{21}$

Kekuatan korelasi antara ratio TG/HDL dengan kadar HbA1c darah yang ditemukan tergolong rendah. Karena masih banyak faktor yang mempengaruhi kadar trigliserida dan HDL darah selain HbA1c. Karena saat ditinjau dari segi patogenesisnya DM tipe 2, ada probabilitas yang menjadi faktor dominan dalam meningkatkan ratio TG/HDL adalah durasi menderita DM tipe 2.

Keterbatasan penelitian ini adalah rancangan potong lintang di mana belum semua variabel perancu (lama menderita DM, penggunaan obat penurun lipid) dapat dikontrol dengan baik. Berdasarkan hasil penelitian yang dilakukan terhadap data 59 pasien yang berobat ke RSUP Dr. Kariadi Semarang, dapat disimpulkan bahwa tidak terdapat hubungan/korelasi positif antara ratio TG/HDL dengan kadar $\mathrm{HbA1c}$.

\section{DAFTAR PUSTAKA}

1. Konsensus. Pengelolaan dan Pencegahan DM Tipe 2 di Indonesia 2015. PB PERKENI; Cetakan Pertama, Juli 2015.

2. Agusta YLA. Deskripsi Pasien Diabetes di suatu Masyarakat di Jawa Barat. Buku Program dan kumpulan ringkasan. Simposium Nasional Endokrinologi II Bandung 1995 hal 3.

3. Penatalaksanaan diabetes melitus terpadu, Balai Penerbit FKUI, Jakarta; Edisi kedua, Cetakan ke-9: 2013.

4. Suastika, K. Pengelolaan Kaki Diabetik Terinfeksi, Dalam: Kumpulan Naskah Ilmiah Obesitas, Sindrom Metabolik, Diabetes, Dislipidemia, Penyakit Tiroid. Bali: Udayana University Press. 2008. H. 154.

5. Wild S, Roglic G, Green A, King H, et al. Global Prevalence of Diabetes Estimate for the year 2000 and Projection for 2030. Diabetes Care. 2004;27(5):1047-1053.

6. World Health Organization (WHO). Media Center Diabetes. Diperoleh dari: http://www.who.int/index.html. Diakses tanggal 18 Januari, 2016.

7. Diabetes Atlas.org. 2015. Diunduh tanggal 18 Januari 2016.

8. Smeltzer, Suzanne C. dan Bare, Brenda G, 2002, Buku Ajar Keperawatan Medikal Bedah Brunner dan Suddarth (Ed.8, Vol. 1,2), Alih bahasa oleh Agung Waluyo (dkk), EGC, Jakarta

9. http://www.depkes.go.id/article/print/414/tahun-2030prevalensi-diabetes-melitus-di-indonesia-mencapai-213-jutaorang.html. Di unduh tanggal 18 Januari 2016.

10. https://www.google.co.id/search?q=litbangkes $+2008+$ diabetes\&biw $=$. Diunduh tanggal 18 Januari 2016

11. Dinkes Provinsi Jawa Tengah, 2008. Di unduh tanggal 18 Januari 2016. 
12. Profil Kesehatan Kota Semarang, 2009. Diunduh tanggal 18 Januari 2016.

13. Pandelaki K. Diabetic Dyslipidemia Management, The First East Indonesia Endo-Metabolic Update, Perkeni Cabang Makassar, 2006; 24-31.

14. Jalal F, Liputo N, Susanti N,Oenzil F. Hubungan Lingkar Pinggang dengan Kadar Gula Darah. Trigliserida, dan Tekanan Darah pada Etnis Minang di Kabupaten Padang Pariaman, Sumatera Barat. Diperoleh dari: repository.unand.ac.id.

15. Kusniyah Y, Nursiswati, Rahayu U. Hubungan Tingkat Self Care dengan Tingkat HbA1c Pada Klien Diabetes Melitus Tipe 2 di Poliklinik Endokrin RSUP DR. Hasan Sadikin Bandung. Diperoleh dari: pustaka.unpad.ac.id.

16. Adam John MF. Reducing Cardiovascular Risk in: Type 2 Diabetes From the Lipidologist View, Buku Ringkasan Diabetes dan Kelainan Terkait, Perkeni, Makassar, 2004:12.
17. Hendromartono. Penuntun Penatalaksanaan Dislipidemia di Indonesia. Naskah Lengkap The Metabolic Syndrome, Pusat Diabetes dan Nutrisi RSU Dr. Soetomo - FK Unair, Surabaya, 2006; 29-31.

18. Oputa RN, Chinenye S. Diabetes Mellitus: A Global Epidemic With Potential Solutions. African Journal of Diabetes Medicine [serial online] 2012 November; 20(2):[hal33].

19. Pasca.unand.ac.id/.../hubungan-glycosylated haemoglobi. Diakses tanggal 10 Februari 2016.

20. Ejournal.unsrat.ac.id/index.php/eclinic/article/viewFile/ 3614/3142. Diakses tanggal 10 Februari 2016.

21. Khan HA, Sobki S.H, Khan S.A. Clinical and Experimental Medicine: Association Between Glycaemic Control and Serum Lipids Profile In Type 2 Diabetic Patients, vol. 7: SpringerVerlag, 2007.p, 24-9. 